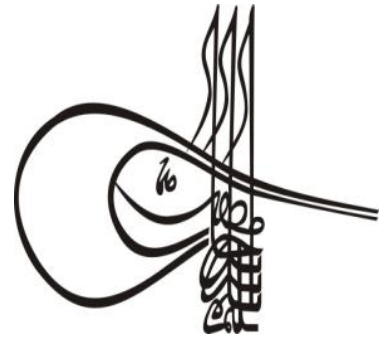

Received/Geliş: 07.06.2019

\section{Turkigh Studies Educational Sciences}

Volume 14 Issue 4, 2019, p. 1041-1059 DOI: 10.29228/TurkishStudies.23292

ISSN: 2667-5609

Skopje/MACEDONIA-Ankara/TURKEY

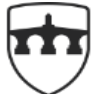

INTERNATIONAL BALKAN UNIVERSITY

EXCELLENCE FOR THE FUTUR IBU.EDU.MK

Research Article / Araştırma Makalesi

Article Info/Makale Bilgisi

$\checkmark$ Accepted/Kabul: 10.08 .2019

Gor Report Dates/Rapor Tarihleri: Referee 1 (22.07.2019)-Referee 2 (23.07.2019)

This article was checked by iThenticate.

\title{
SINIF ÖĞRETMENLERINIIN FEN KAVRAM YANILGILARININ BELİRLENMESİ
}

\author{
Menşure ALKIŞ KÜÇÜKAYDIN*- Şafak ULUÇINAR SAĞIR**
}

\begin{abstract}
öz
Kavram yanılgıları konusunda yürütülen çalışmalar, kavram yanılgılarının oldukça derin köklere sahip olduğunu ve bazen öğretim etkinliklerinden sonra da devam edebileceğini göstermektedir. Bu durum sınıf ortamında öğretmene kavram yanılgılarının doğru bir biçimde teşhis edilmesi ve öğretimden önce nedenlerinin ortaya çıkarılması gibi görevler yüklemektedir. Ancak görev başındaki öğretmenlerle yürütülen çalışmalar, öğretmenlerin pek çok konuda kavram yanılgısına sahip olduğunu ve bunu öğrencilerine yansıttıklarını işaret etmektedir.

$\mathrm{Bu}$ çalışmada görevi başındaki sınıf öğretmenlerinin fene yönelik kavram yanılgıları tarama yöntemiyle belirlenmeye çalışılmıştır. Çalışmanın örneklemini Konya ilinin büyük bir ilçesinde görev yapmakta olan sınıf öğretmenleri oluşturmuştur. Toplam 120 sınıf öğretmeniyle yürütülen çalışmada, veri toplama aracı olarak hem test şeklinde hem de açık uçlu soruların yer aldığı kavram yanılgısı belirleme formu kullanılmıștır. Veriler 5 haftalık bir zaman diliminde toplanmıştır. Verilerin analizinde kavram yanılgısı kesinlik indeksi ile forma verilen yanıtların bilimsel olarak kabul edilebilirliğini temsil eden kategoriler kullanılmıştır.

Çalışma sonucuna göre öğretmenlerin fenin farklı konularında kavram yanılgılarına sahip oldukları ve açık uçlu sorulara verdikleri yanıtların bilimsel olarak kabul edilemeyen kategoriye ait olduğu görülmüsstür. Sinıf öğretmenleriyle yürütülen bu çalışma esasında sınıf öğretmenlerinin kavram yanılgılarına ilişkin ne bildikleri, öğretimlerinde
\end{abstract}

Dr.Öğr.Üyesi, Necmettin Erbakan Üniversitesi Ereğli Eğitim Fakültesi Temel Eğitim Bölümü Sınıf Eğitimi ABD, Eposta: mensurealkis@gmail.com 
buna nasıl yer verdikleri ve öğretimlerinde karşılaşacakları yanılgılar noktasında nasıl bir düzenlemeye gidecekleri noktasında da 1 ş1k tutmaktadır. Çünkü elde edilen bulgulara göre sınıf öğretmenlerinin ilgili literatürde daha önce ilkokul, ortaokul, lise ve üniversite ögrencilerinde var olan kavram yanılgıları ile benzer yanılgılara sahip oldukları tespit edilmiştir. Elde edilen sonuçlara dayanarak, sınıf öğretmenlerinin bilimsel olarak kavram yanılgıları ile yüzleşmeye hazır hale getirilmesi ve kendilerini yenileme noktasinda isteklerinin artırılması, geliştirilecek ulusal öğretmen yetiştirme hedefleri arasına sokulabilir.

Anahtar Kelimeler: fen, kavram yanılgısı, sınıf öğretmeni

\title{
DETERMINING OF SCIENCE MISCONCEPTIONS OF PRIMARY SCHOOL TEACHERS
}

\begin{abstract}
Studies on misconceptions show that misconceptions have deep roots and may be sometimes continue after teaching activities. In the classroom environment, the teacher assigns tasks such as correct identification of misconceptions and revealing reasons before teaching. However, studies conducted with teachers in the service indicate that teachers have misconceptions on many issues and reflect this to their students.

In this study, it was tried to determine the misconceptions of the primary school teachers in the service. The sample of the study consisted of primary school teachers working in a large district of Konya In the study conducted with total 120 primary school teachers, as a data collection tool, misconception determination form which includes both test and open ended questions was used. Data were collected over a 5-week period.In the analysis of the data, the certainty of response index and the categories representing the scientific acceptability of the responses to the form were used.

According to the results of the study, it was seen that teachers had misconceptions about different subjects of science and their answers to open-ended questions belonged to the scientifically unacceptable category. In fact, this study conducted with primary school teachers sheds light on what they know about misconceptions of primary school teachers, how they place this in their teaching and how they will arrange for the misconceptions they will encounter in their teaching. Because, according to the findings, it was found that primary school teachers had similar misconceptions with primary, secondary, high school and university students the existed in the related literature. Based on the results obtained, the preparation of primary school teachers to confront scientifically misconceptions and increasing their desire to renew themselves can be included in the national teacher training objectives to be developed.
\end{abstract}




\section{STRUCTURED ABSTRACT}

\section{Introduction}

Many studies conducted in science education since the mid-1970s show that students in different age groups have misconceptions in different subject areas. For this reason, the teacher must be actively involved in the process of accurate diagnosis of misconceptions and revealing the reasons before teaching and ultimately re-conceptualizing learning. However, this raises the question of how teaching and conceptual change will occur if the teacher has misconceptions. In the related literature, it has been observed that there are many studies on the misconception in different subjects of science, especially with preservice teachers. It has been observed that the amount of studies conducted on misconceptions with teachers is quite limited, especially with teachers in science field (physics, chemistry, biology teaching) and these studies no included in the recent period. However, the studies conducted with the primary school teachers in the examined abroad literature were found to be quite limited and no study was found in our country. In this study, it is tried to reveal misconceptions that might be in the primary school teachers.

\section{Method}

This study, in which the science misconceptions of the primary school teachers were determined, was a descriptive study and was carried out in the survey model. The universe of the study consists of 520 classroom teachers serving in 64 primary schools in a large district of Konya province in the 2018-2019 academic year. No sampling was made in the study and all primary school teachers were tried to be reached. However, the number of teachers who can be reached and willing to participate in this study voluntarily is 120 . In this study, which was conducted in order to determine the misconceptions about science of primary school teachers, an application form containing misconceptions about science and teachers' demographic information was questioned was used. There are 9 questions in the application form. The certainty of response index to misconceptions was used for the analysis of the test type questions directed to the primary school teachers. In the analysis of open-ended questions, categories were used according to the level of comprehension of the answers to the questions. Teachers' responses were evaluated as "scientifically acceptable," scientifically partly acceptable and "scientifically unacceptable".

\section{Findings}

According to the findings obtained from the answers given to the test type questions directed to the primary school teachers, $17.7 \%$ of the teachers used the expressions which have misconceptions. $9.02 \%$ of the teachers responded correctly to the questions asked, but they did not fully explain and the certainty of response index was considered to be low. $2.59 \%$ of the teachers' expressions were given a wrong answer, but these statements were not considered as misconception. Because the certainty of response index in the statements were found to be low. When the answers given to the application form are examined, it is seen that $62.3 \%$ of the teacher expressions fully explain the concept and the concept gains are realized. When the answers to open-ended questions 
are examined, it is seen that the answers given outside the expression "I do not know", are mostly in "scientifically unacceptable" category.

\section{Discussion and Conclusion}

On the basis of this study carried out with the primary school teachers, they also shed light on how they know about the misconceptions of primary school teachers, how they include it in their teaching and how they can make arrangements in terms of the misconceptions they will encounter in their teaching. As so the findings, it is seen that primary school teachers have similar misconceptions with primary school, secondary school, high school and university students in the related literature. This is an issue that needs to be emphasized, corrected and clarified. However, it is seen that there is a need for sound planning with the teachers in service considering the difficulties encountered in both application and data collection point. Therefore, there is a need for qualified projects in order to prepare this planning not only at the local level but also at the national level. The concept knowledge that a science teacher will need and the need of the primary school teacher will differ in perspective. Therefore, at this point, first of all, it can be suggested to start the work by measuring the level of knowledge and the level of the expert knowledge of the primary school teachers in the classroom environment.

Keywords: misconceptions, primary school teacher, science

\section{Giriş}

İlkokul fen eğitiminde yapılan öğretim düzenlemeleri ve program değişiklikleri, fen kavramlarını ve fene yönelik anlamaları günlük yaşamlarıyla ilişkilendirerek anlamaya çalışan öğrencilerin yetiştirilmesini hedeflemektedir (Milli Eğitim Bakanlığ1 [MEB],2018). Geleneksel yaklaşıma sahip öğretmen eğilimlerinin ise öğrencilerin belirli adımları izledikleri ve önceden belirlenmiş sonuçlara ulaşmalarını sağlayan, bilme ve bilmenin ne anlama geldiği konusunda yetersiz kavramsal anlayışla sonuçlanan bilim anlayışına sahip oldukları yönünde olduğu görülmektedir (Cheung, Ma \&Yang, 2009). Bu anlayış öğrenci fikirlerini kimi zaman görmezden gelmekte kimi zaman da öğrencilerin bilimle ilgili yeni bilgiler öğrenmeye karşı ilgisiz olduğunu varsaymaktadır (Gomez-Zwiep, 2008). MEB (2018) tarafından fen programında yapılan değişiklikler ve benimsenen temel misyonun öğrencilerin bilimi daha iyi öğrenmelerine yardımcı olacak bir araç olarak bilimsel ve mühendislik uygulamalarını teşvik ettiği görülmektedir. Bu uygulamaların yerinde ve doğru olarak yürütülebilmesinde ise öğretmenin rolü göze çarpmaktadır. Bilimsel uygulamalarda, öğrencilerin bireysel ve toplu olarak soruna yönelik bir çözüm geliştirmesi ve değerlendirilmesi ile ilgili kritik kararlar alması gereklidir. Bu da öğretmenin dikkate değer bir sorunu yapılandırması ve iyi bir rehberlik hizmeti sunması ile sağlanabilir (Dankenbring \& Capobianco, 2016).

Fen eğitiminde 1970'lerin ortasından beri yürütülmekte olan pek çok çalışma farklı yaş gruplarında yer alan öğrencilerin, farklı konu alanlarında kavram yanılgılarına sahip olduğunu göstermektedir (Gomez-Zwiep, 2008). Esasında öğretimde yer alan hedefler dışında meydana gelen kavram yanılgıları ilgili literatürde alternatif kavramlar, yanlış kavramlar, alternatif çerçeveler, naif inançlar, önyargılar gibi farklı şekillerde ifade edilmiş ancak tüm bu ifade biçimlerinde genel olarak kabul edilen görüş; bilimsel anlayışın dışında yer alan çerçeve olarak benimsenmiştir (Subayani, 2016). Bu çalışmada ise kavram yanılgısı terimi kullanılmış olup, bilimsel olarak kabul edilen görüşlerle uyuşmayan fikirler biçiminde yapılan açıklamalara atıfta bulunulmuştur. 
Kavram yanılgıları, öğrenci öğrenmelerinde önemli bir etkiye sahiptir. Kavram yanılgılarından arındırılmış bir öğrenme ortamında, kavram öğrenimi daha anlamlı olacak ve yeni bilgi inşası sağlam olacaktır (Pablico, 2010). Kikas (2004) kavram yanılgılarının kaynakları olarak analojilerin aşırı genelleştirilmesi, ontolojik açıdan farklı kategorilere ait kavramların karıştııılması, ders kitaplarında sunulan bilgiler ile öğretmen bilgisine işaret etmektedir. Kavram yanılgıları konusunda yürütülen çalışmalar, kavram yanılgılarının oldukça derin köklere sahip olduğunu ve bazen öğretim etkinliklerinden sonra da devam edebileceğini göstermektedir (Gomez-Zwiep, 2008). Bu nedenle kavram yanılgılarının doğru bir biçimde teşhis edilmesi ve öğretimden önce nedenlerinin ortaya çıkarılması ve sonuçta öğrenmenin yeniden kavramsallaştırılması sürecinde öğretmenin aktif rolde olması gerekmektedir. Ancak bu durum öğretmenin de kavram yanılgılarına sahip olması durumunda öğretimin ve kavramsal değişimin nasıl gerçekleşeceği sorusunu beraberinde getirmektedir. Meyer (2004) öğretmen adaylarının ve 10 yıllık öğretim tecrübesine sahip öğretmenlerin kavram bilgilerini incelediği çalışmasında, deneyimli öğretmenlerde ön bilgilerin yaşam deneyimine bağlı olarak geliştiği düşüncesinin, aday öğretmenlerde ise ön bilgilerin formal ya da informal öğrenme ortamları yoluyla geliştiği düşüncesinin olduğunu belirlemiştir. Ayrıca öğretmen adaylarının, öğretim sırasında öğrencilerin ön bilgilerini teşhis etmek ve bu ön bilgileri ele almak için kullanılan öğretim stratejilerinden haberdar olmadıklarını tespit etmiştir. Gomez-Zwiep (2008) 1-30 yıllık öğretim deneyimine sahip öğretmenlerin kavram yanılgıları konusundaki bilgi durumlarını incelediği çalışmasında, öğretmenlerin birçoğunun kavram yanılgılarının farkında olduğunu ancak bu yanılgıların nasıl geliştiği ve öğretimlerinde bu konuda nasıl etkili olabilecekleri konusunda açıklama yapamadıklarını belirtmiştir. Hashweh (1987) kimi öğretmenlerde, öğrencilerde var olan kavram yanılgılarının aynısına rastlanıldığını belirtirken Barrass (1984), Sanders (1993) ve Yip (1996) öğretmen yanılgılarının öğrencilere aktarıldığını ve öğretimleri yoluyla da bu durumun pekiştirildiğini savunmaktadırlar. Lawrenz (1986) Amerika Birleşik Devletleri'nde aday sınıf öğretmenlerinin madde, yoğunluk, 1şık, yıldızlar ve elektrik konularındaki kavramlarla ilgili bilimsel anlayışlarını ortaya çıkarmaya çalıştığı çalışmasında, öğretmen adaylarının \%50'sinin kendilerine sorulan soruları doğru cevapladığını belirtmiştir. Öğretmenlerin vermiş olduğu yanlış yanıtların büyük bir kısmının yetersiz içerik bilgisinden kaynaklandığını belirten Lawrenz (1986) yanlış cevapların diğer bir nedeni olarak kavram yanılgılarını işaret etmiştir. Kruger, Palacio ve Summers'in (1992) ilkokul öğretmenlerinin kuvvet konusundaki anlamalarını ortaya çıkarmaya çalıştıkları araştırma sonuçlarına göre öğretmenlerin büyük çoğunluğu kuvvet konusunda belirsiz ifadeler kullanmışlar ve ağırlık ile yerçekimi kuvveti arasındaki ilişkiden haberdar olmadıkları sonucuna ulaşılmıştır. Farklı kültürlerden öğrenci ve öğretmen kavram yanılgılarının karşılaştırıldığı ve kavram yanılgılarının kültüre özgü bir durum olup olmadığının araştırıldığ çalışmalarda ise kavram yanılgılarının benzer olduğu tespit edilmiştir (Trumper, Raviolo \& Shnersch, 2000).

İlgili literatürde özellikle öğretmen adaylarıyla, fenin farklı konularında kavram yanılgısı çalışmalarının yoğun bir biçimde yürütüldüğü görülmüştür (Akgün, Gönen \& Yılmaz, 2005; Arslan, Çiğdemoğlu \& Moseley, 2012; Bayraktar, 2009; Çıbık, 2017; Erduran Avcı, Kara \& Karaca, 2012; Eyceyurt Türk \& Tüzün, 2018; Kaptan \& Korkmaz, 2001; Naah, 2015; Yates \& Marek, 2014). Eyceyurt Türk ve Tüzün'e (2018) göre öğretmenlerin fen kavramları konusunda yetersiz olmaları durumunda, eğitimin bir parçası olarak öğrencilerin yetersiz kalacağı belirtilmiştir. Ortaokul ve lise kademesinde yer alan öğrencilerle yürütülen kavram yanılgısı çalışmaları bu yetersizlikleri ortaya çıkarmaktadır (Buluş Kırıkkaya \& Güllü, 2008; Dankenbring \& Capobianco, 2016; Koray, Özdemir \& Tatar, 2005; Pine, Messer \& John, 2001). Öğretmenlerle kavram yanılg1sı konusunda yürütülen çalışma sayısının ise oldukça sınırlı olduğu ve özellikle fen alanındaki öğretmenlerle (fizik, kimya, biyoloji öğretmenliği) çalışıldığı ayrıca son dönemlerde bu çalışmalara sıklıkla yer verilmediği görülmüştür (Barrass, 1984; Cheung vd., 2009; Hashweh, 1987; Sanders, 1993; Yip, 1998). Bununla birlikte taranan yurt dışı literatürde sınıf öğretmenleriyle yürütülen çalışmaların oldukça sınırlı olduğu (Kikas, 2004; Kruger vd., 1992; Trumper vd., 2000) görülmüş ülkemizde ise bu konuda herhangi bir çalışmaya rastlanılmamıştır. Kikas'a (2004) göre hiç araştırma yapılmamış bir öğretmen grubunda da 
bir dizi yanlış kavramaların olduğunu varsaymak oldukça mantıklıdır. Bu çalışmada da sınıf öğretmenlerinde olması muhtemel kavram yanılgıları ortaya çıkarılmaya çalışılmıştır. Daha önce sınıf öğretmenleriyle yürütülen herhangi bir kavram yanılgısı çalışmasına rastlanılmadığından ilgili literatürde ilkokul, ortaokul ve lise öğrencileri ile öğretmen adaylarında tespiti yapılan kavram yanılgıları üzerinden hareket edilmiştir. Bu yanılgılar fenin temel kimya, biyoloji ve fizik konularını içerecek biçimde düzenlenmiş ve sınıf öğretmenlerinin yanılgıları açı̆̆a çıkarılmaya çalışılmıştır.

\section{Yöntem}

Sınıf öğretmenlerinin fen kavram yanılgılarının belirlendiği bu çalışma betimsel araştırma niteliğinde olup tarama modelinde yürütülmüştür. "Tarama modelleri, geçmişte ya da halen var olan bir durumu var olduğu şekliyle betimlemeyi amaçlamaktadır. Araştırmaya konu olan olay, birey ya da nesne, kendi koşulları içinde ve olduğu gibi tanımlanmaya çalışılır" (Karasar, 2013: 77). Bu çalışmada da sınıf ögretmenlerinin fene yönelik var olan kavram yanılgıları bir olgu olarak nitelendirilmiş ve bu olgu betimlenmeye çalışılmıştır.

\section{Evren ve Örneklem}

Bu çalışmanın evrenini 2018-2019 eğitim öğretim yılında Konya iline bağlı büyük bir ilçenin; ilçe merkezi, köy, kasaba ve birleştirilmiş sınıflı olmak üzere toplam 64 ilkokulda hizmet veren 520 sınıf öğretmeni oluşturmaktadır. Çalışmada örneklem alma yoluna gidilmemiş ve tüm sınıf öğretmenlerine ulaşılmaya çalışılmıştır. Ancak ulaşılabilen ve gönüllü olarak bu çalışmaya katılmak isteyen öğretmen sayıs1 120'dir. Çalışmada yer alan öğretmenlere ilişkin demografik bilgiler Tablo 1 'de sunulmuştur.

\begin{tabular}{|c|c|c|c|c|c|c|}
\hline \multicolumn{7}{|c|}{ Hizmet Yılı } \\
\hline \multirow[t]{2}{*}{ Değişkenler } & $0-5$ & $6-10$ & $11-15$ & $16-20$ & 21 Yllve & Toplam \\
\hline & Yll & Yll & $Y l l$ & $Y l l$ & üstü & \\
\hline Kadın & 2 & 7 & 3 & 18 & 23 & 53 \\
\hline Erkek & 0 & 2 & 4 & 18 & 43 & 67 \\
\hline Toplam & 2 & 9 & 7 & 36 & 66 & 120 \\
\hline \multicolumn{7}{|c|}{ Eğitim Durumu } \\
\hline Değişkenler & Öğret & n Lisesi & $\begin{array}{c}\text { Ön } \\
\text { lisans }\end{array}$ & Lisans & $\begin{array}{l}\text { Yüksek } \\
\text { Lisans }\end{array}$ & Toplam \\
\hline Kadin & & & 8 & 42 & 2 & 53 \\
\hline Erkek & & & 19 & 43 & 2 & 67 \\
\hline Toplam & & & 27 & 85 & 4 & 120 \\
\hline \multicolumn{7}{|c|}{ Mezun Olunan Okul } \\
\hline Değişkenler & Eğitin & akültesi & $\begin{array}{c}F e n- \\
F a\end{array}$ & $\begin{array}{l}\text { ebiyat } \\
\text { tesi }\end{array}$ & Diğer & Toplam \\
\hline Kadın & & & & & 13 & 53 \\
\hline Erkek & & & & & 16 & 67 \\
\hline Toplam & & & & & 29 & 120 \\
\hline
\end{tabular}

Tablo 1'de yer alan bilgilere göre çalışmaya toplam 53 kadın ve 67 erkek sınıf öğretmeni katılmıştır. Katılımcılardan toplam 66 kişi 21 yıl ve üzerinde, 36 kişi 16-20 yıl, 7 kişi 11-15 yıl, 9 kişi 6-10 yıl ve 2 kişi ise $0-5$ yıl aralığında hizmet süresine sahiptir. Öğretmenlerin büyük bir bölümü lisans mezunu iken (85 kişi) 4 kişi öğretmen lisesi mezunudur. Katılımcılardan 4'ü ise yüksek lisans eğitimini tamamlamıştır. Bununla birlikte katılımcı öğretmenlerden 84 'ü eğitim fakültesi, 4'ü ise fenedebiyat fakültesi mezunudur. Diğer olarak adlandırılan 29 kişilik grupta ise eğitim yüksekokulu, ziraat fakültesi, işletme, maliye, mühendislik, sağlık yüksekokulu ve teknik eğitim fakültesi mezunları yer almaktadir. 


\section{Veri Toplama Araçları}

Sınıf öğretmenlerinin fenle ilgili kavram yanılgılarının tespit edilmesi amacıyla yürütülen bu çalışmada, öğretmenlere ait demografik bilgilerin sorgulandığı bir form ile ilgili kavram yanılgılarının yer aldığı bir uygulama sayfası kullanılmıştır. Kavram yanılgıları ile ilgili uygulama sayfasının hazırlanmasında ilk olarak kapsamlı bir literatür taraması yapılmıştır. Yapılan tarama sonucu ilkokul düzeyinde tespiti yapılan yanılgılar listelenmiştir. Bu yanılgılar arasından temel kimya, biyoloji ve fizik konularına eşit sayıda yer verilecek biçimde bir form hazırlanmıştır. Hazırlanan bu form öncelikle bir fen bilgisi öğretmeninin görüşleri alınarak düzenlenmiştir. İlgili literatürden alınan ifadeler öğretmenlere sorulmadan önce fen eğitimi alanında doktorasını tamamlamış bir uzmana da gönderilmiş ve böylece yanılgıların son kez teyidi gerçekleştirilmiştir. Böylelikle 6 soru "evet", "hayır" ve "bilmiyorum" seçeneklerinden birinin işaretlenip ardından gerekçelerinin istendiği test şeklinde, 3 soru ise açıklama gerektiren açık uçlu bir şekilde hazırlanmıştır. Soruların bu şekilde hazırlanması ile öğretmenlere ait düşünce yapısı hakkında daha çok bilgi elde edilmesi hedeflenmiştir. İlgili literatürde kavram yanılgılarının teşhisi aşamasında bu çalışmada olduğu gibi test tipi (Çakır \& Aldemir, 2011) ve açık uçlu sorulardan yararlanıldığı görülmektedir (Alkış, 2006; Ayvacı ve Şenel Çoruhlu, 2009; Çavdar, Okumuş \& Doymuş, 2016; Güler \& Şahin, 2017; Selvi \& Yakışan, 2004). Kullanılan bu yöntemler sayesinde kavramların anlaşılma düzeyleri ya da yanlış anlaşılmalar ortaya çıarılabilmektedir (White \& Gustone, 1992). Formun son halinde yer alan test tipi sorular şu şekildedir:

1. Tohumlar canlı midır? (Tamir, Gal-Chappin\&Nussnovitz, 1981),

2. Balina bir balık midır? (Trowbridge \& Mintzes, 1988),

3. Tamamen karanlık bir odada beyaz bir kağıdı görebilir miyiz? (Şahin, İpek \&Ayas, 2008),

4. Uçaktan aşağıya atlayan bir kişi üzerinde herhangi bir yerçekimi kuvveti var mıdır? (Pablico, 2010),

5. Paslanmış demir, paslanmadan önce tartılmış demirden ağır mıdır? (Allen, 2014),

6. Aşağıdaki görselde yer alan kişi bisiklet kullanmaktadır. Bisiklette herhangi bir fren sistemi yok ayrıca pedal çevrilmemektedir. Ancak bisiklet yavaşlamaktadır. Bisiklet üzerinde herhangi bir kuvvet söz konusu mudur? (Pablico, 2010)

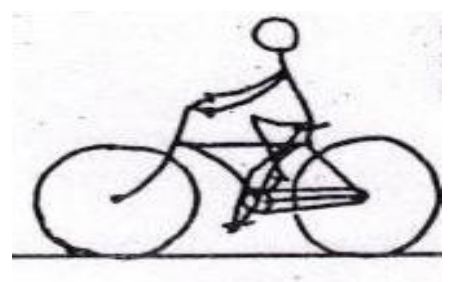

Formda yer alan açık uçlu sorular ise şu şekilde hazırlanmıştır:

1. Küçük çocuklardaki kalp atış hızının fazla olmasının nedeni nedir?

2. Yaz mevsiminde gündüz süresinin uzun olmasının sebebi nedir?

3. Aşağıdaki görselde yer alan aynı cins toplar eşit yükseklikten aynı anda bırakılırsa, hangisi yere daha hızlı düşer? Nedenini açıklayınız. 


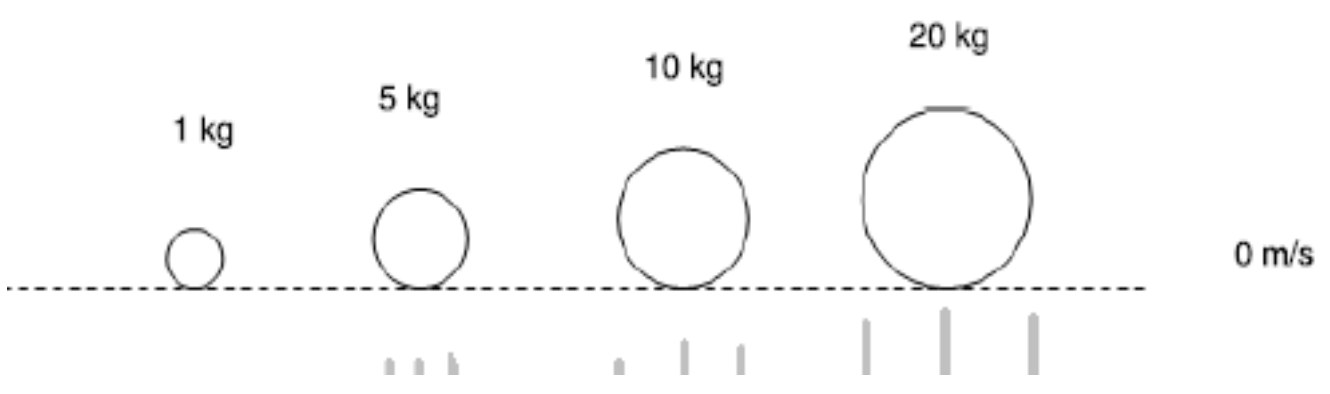

\section{Verilerin Toplanması}

Bu çalışmada kullanılan veri toplama araçlarının uygulama safhası 2018-2019 eğitim öğretim yılının güz döneminde gerçekleştirilmiştir. Uygulama için öncelikle Milli Eğitim Bakanlığından araştırma uygulama izni ardından Konya İl Milli Eğitim Müdürlügünden alınan gerekli izinler doğrultusunda okullar ziyaret edilmiştir. Her okulda sınıf öğretmenlerine, çalışmanın amacından bahsedilmiş ve gönüllülük esası doğrultusunda katılımlarının beklendiği söylenmiştir. Çalışmaya katılmak isteyen öğretmenlere uygulama formu teslim edilmiş ve bir hafta sonra formlar toplanmak üzere aynı okullara tekrar gidilmiştir. İlçe genelinde yer alan toplam 12 okula bu şekilde ulaşılmış ve tüm bu süreç 5 hafta boyunca tekrarlanmıştır. Ancak uygulamadan önce çalışmaya katılmayı kabul eden öğretmenlerden bazıları uygulama formundaki soruları gördükten sonra vazgeçmişler ve çalışmaya katılmak istememişlerdir. Gerekçe olarak da daha önce bu şekildeki sorularla hiç karşılaşmadıklarını, bu soruların cevabını hiç düşünmediklerini ve sınıf ortamında bu bilgilere gerek duymadıklarını belirtmişler ve sert bir biçimde uygulamaya karşı çıkmışlardır. $\mathrm{Bu}$ nedenle öğretmenlere dağıtılan formların büyük bir bölümünden geri dönüş sağlanamamıştır.

\section{Verilerin Analizi}

Sınıf öğretmenlerine yöneltilen test tipindeki soruların analizi için Hasan, Bagayokove Kelley (1999) tarafından öğrenciler için geliştirilen, kavram yanılgılarına yönelik yanıtların kesinlik indeksi (Certainty of Response Index= CRI) kullanılmıştır. İndekse göre soruların yanıtlanmasında doğru ya da yanlış sorusunun yanı sıra güven düzeyi de sorgulanmaktadır. Subayani’ye (2016) göre, CRI yönteminin kullanılması, bireylerin kavram yanılgısı düzeylerinin haritalanmasında büyük ölçüde yardımcı olmaktadır. Hasan ve arkadaşlarının (1999) geliştirdikleri yöntemde farklı kriterler dikkate alınabilmektedir. Bu yöntem Pablico (2010) tarafından da kullanılmıştır. Buna göre kavram yanılgılarının tespitinde, test tipinde hazırlanan soruların madde yapısına göre belli bir karar oranı belirlenmektedir. Bu çalışma için, kavram yanılgılarının tanımlanmasında kullanılan kriterler Tablo 2'de sunulmuştur.

Tablo 2:Kavram yanılgıları için karar matrisi (Subayani, 2016)

\begin{tabular}{|c|c|c|}
\hline Cevap & Düşük CRI & Yüksek CRI \\
\hline Doğru & $\begin{array}{l}\text { Cevap doğru ancak kavram yanılgısı } \\
\text { sorusuna verilen cevabın kesinlik oranı } \\
\text { düşük: Kavram anlaşılmamış }\left(\mathrm{KA}_{1}\right)\end{array}$ & $\begin{array}{l}\text { Doğru cevap ve kavram yanılgısı } \\
\text { sorusuna verilen cevabın kesinlik oranı } \\
\text { yüksek: Kavram kazanılmış }(\mathrm{KK})\end{array}$ \\
\hline Yanlış & $\begin{array}{l}\text { Cevap yanlış ve kavram yanılgısı } \\
\text { sorusuna verilen cevabın kesinlik oranı } \\
\text { düşük: Kavram anlaşıllmamış }\left(\mathrm{KA}_{2}\right)\end{array}$ & $\begin{array}{l}\text { Cevap yanlış ama kavram yanılgısı } \\
\text { sorusuna verilen cevabın kesinlik oranı } \\
\text { yüksek: Kavram yanılgısı (KY) }\end{array}$ \\
\hline
\end{tabular}

Tablo 2'ye göre kendilerine yöneltilen soruya doğru cevap veren ancak yeterli açıklama yapamayan ya da açıklamasından emin olmayan ifadeler için kavram anlaşılmamış $\left(\mathrm{KA}_{1}\right)$, kendilerine yöneltilen soruyu doğru cevaplayıp tam olarak açıklayabilen ifadeler için kavram kazanılmış (KK), kendilerine yöneltilen soruya yanlış cevap vermiş ancak cevabından emin olamayan ya da yanlış seçeneğini işaretleyip tam olarak açıklayamayan ifadeler için kavram anlaşılmamış $\left(\mathrm{KA}_{2}\right)$, kendilerine 
yöneltilen sorulara yanlış cevap verip bu durumu açılayan ve savunan ifadeler için ise kavram yanılgısı (KY) betimlemeleri kullanılmıştır.

Açık uçlu soruların değerlendirilmesinde ise, sorulara verilen yanıtların anlama düzeylerine göre kategoriler kullanılmıştır. Bu kategoriler ilgili literatürde daha önce pek çok kez kullanılmıştır (Akbaş, 2002; Alkış, 2006; Çavdar vd., 2016; Güler \& Şahin, 2017; Platten, 1995). Bu çalışmada da öğretmenlerin vermiş oldukları yanıtlar "bilimsel olarak kabul edilebilir", "bilimsel olarak kısmen kabul edilebilir" ve "bilimsel olarak kabul edilemez" olarak değerlendirilmiştir. Öğretmen yanıtları bu şekilde sınıflandırılırken, her öğretmenin yanıtları listelenmiş ve uzman görüşleri doğrultusunda sınıflandırma işlemi yapılmıştır. Bu doğrultuda kimya eğitimi alanında bir profesör, fizik eğitiminde iki profesör, biyoloji eğitiminde ise bir profesör ve bir yardımcı doçentten uzman görüşü alınmıştır. Böylelikle değerlendirme sürecinde yanlılığın önüne geçilmiştir.

\section{Bulgular}

\section{Test Tipi Sorularda Tespit Edilen Kavram Yanılgıları}

Sınıf öğretmenlerinin uygulama formuna vermiş oldukları yanıtlar doğrultusunda betimsel analizler yapılmıştır. Buna göre yanıtlardan elde edilen bulgular Tablo 3'te sunulmuştur.

\begin{tabular}{|c|c|c|c|c|c|}
\hline \multicolumn{6}{|c|}{ Tablo 3: Test tipi sorulara verilen yanıtların analizi } \\
\hline Soru & \multirow{2}{*}{\multicolumn{2}{|c|}{ Düşük CRI }} & & & \\
\hline & & & \multicolumn{2}{|c|}{ Yüksek CRI } & \multirow{2}{*}{$\begin{array}{c}\text { Bilmiyorum } \\
(f)\end{array}$} \\
\hline & $K A_{l}(f)$ & $K A_{2}(f)$ & $K K(f)$ & $K Y(f)$ & \\
\hline 1. & 12 & 5 & 101 & 2 & 2 \\
\hline 2. & 1 & 8 & 69 & 40 & 2 \\
\hline 3. & 0 & 0 & 98 & 19 & 2 \\
\hline 4. & 5 & 0 & 106 & 4 & 5 \\
\hline 5. & 3 & 6 & 32 & 55 & 24 \\
\hline 6. & 45 & 0 & 50 & 10 & 15 \\
\hline
\end{tabular}

Tablo 3’te sınıf öğretmenlerinin kendilerine yöneltilen test tipi sorulara verdikleri yanıtların, kesinlik indeksine göre analiz sonuçları yer almaktadır. Buna göre birinci soru olan tohumların canlılığı konusunda 101 sinıf öğretmenin kavramı tam olarak kazandığı ve durumu açıkladığı, 12 öğretmenin doğru cevap verdiği ancak verilen cevabın kesinlik oranının düşük olduğu, 5 öğretmenin yanlış cevap verdiği ancak verilen yanlış cevapta kesinlik oranının düşük olduğu görülmektedir. $\mathrm{Bu}$ soruda 2 öğretmenin ise kavram yanılgısına sahip olduğu görülmüştür. Kavram yanılgısına sahip ifadelerden biri "Canlı değildir. Çünkü yaşam özellikleri olan solunum, beslenme, büyüme ve üreme ile çoğalma olmaz" biçiminde olmuştur. İkinci soruda balinanın balık olup olmama durumu sorulmuş ve 69 öğretmenin kavramı tam olarak kazandığ 1 , 40 öğretmenin ise kavram yanılgısına sahip olduğu görülmüştür. Kavram yanılgısına sahip ifadelerden bazıları şu şekilde olmuştur: "Çünkü suda yaşar ve tüm balık özelliklerini gösterir", "Solungaçları vardır. Deniz canlısıdırlar", "Akciğer solunumu yapması balık olmasına engel değildir”. Bu soruya verilen yanlış ama kesinlik oranı düşük 8 cevap bulunmaktadır. Bu cevaplarda öğretmenlerin tereddüde düşen çelişkili ifadeleri ve cevaplarından tam olarak emin olamadıkları görülmektedir: "Yüzen memelidirler aslında", "Memeli balıktır", "Doğuran memeli balıktır". Tamamen karanlık bir ortamdaki beyaz kağıdı görebilme durumuyla ilgili soruda, sınıf ögretmenlerinin ya kavramı tam olarak kazandıkları ya da kavram yanılgısına sahip oldukları görülmüştür. 19 sınıf öğretmeninin bu konuda yanılgıya düştükleri görülmüştür. Örnek ifadeler şu şekildedir: "Mesafe yakınsa görürüz", "Göz belli bir süre sonra karanlı̆̆a alışır ve görürüz”, "Beyaz yansıtıcıdır", "Açık renktir görürüz", "Gözle kağıt arasında ışı oluşumundan dolayı yansıma olabilir ve kă̆ıt beyaz ise görürüz”. Uçaktan atlayan birisinin üzerine etki eden yerçekimi kuvvetinin sorulduğu dördüncü soruda sınıf öğretmenlerinin büyük bir oranda $(f=106)$ kavram kazanımının olduğu görülmektedir. Bununla birlikte 4 öğretmenin "Yerçekimi kuvveti yoktur, sürtünme ve basıncın 
etkisi vardır", "Yerin çekim kuvveti vardır. Herhangi bir şeyin üzerinde olduğu zaman ise bunu uygulamaz", "Yerçekimi Dünya'nın merkezinde olur, ne alaka" ifadelerini kullandıkları görülmektedir. Öğretmenlerin en fazla yanılgıya düştükleri sorunun $(f=55)$ ise beşinci sırada yer alan paslanmış demir sorusu olduğu görülmektedir. Bu soruda verilen "bilmiyorum" cevabı ise diğer sorular arasında en yüksek orandadır $(f=24)$. Yanılgıya düşen öğretmen ifadelerinden bazıları şu şekildedir: "Paslanmaya neden olan bakterilerin ă̆ırlığını da hesaplamak gerekir. Hava ve nemi de işin içine katarsak ă̆ır olur", "Sertlik özelliği azalacağı için öz kütlesi hafifler", "Fiziksel bir değişme yok, aynı kalır", "Üzerindeki ekstra kirlilik ağırlı yapar", "Paslanma sonucu demirin kütlesinde kayıp meydana gelmiştir", "Yapısı değişse de hacmi artar ancak kütlesi (ă̆ırlı̆̆ı) artmaz". Test tipinde hazırlanan son soruda ise herhangi bir pedal çevirme ya da frenin kullanılmadığı bir bisikletteki yavaşlama durumu sorulmuştur. Bu soruya 45 öğretmen doğru cevap vermiş ancak tam olarak açıklayamamışlardır. "Kuvvet vardır ama nasıl bilmiyorum", "Muhtemelen kuvvet var ve eşitlenene kadar hareket ediyor sonra duruyor", "Hava direnci olabilir ama..." benzeri ifadelerin bu kategoride kullanıldığı görüşmüştür. Kavram yanılgısına düşen öğretmenler ise bisikletin yavaşlama nedenini yerçekimi kuvvetine ya da bisikletin üzerindeki kişinin ağırlığıyla ilişkilendirmişlerdir. $\mathrm{Bu}$ soruda 15 ögretmen ise soruya herhangi bir cevap verememişlerdir.

Test tipi sorulara verilen öğretmen yanıtları doğrultusunda, öğretmenlerin ilgili ifadelerdeki kavram kazanımları, kavramın anlaşılmaması ya da kavram yanılgısı oranları ortaya çıkarılmıştır (Tablo 4).

\begin{tabular}{ccccc}
\hline & \multicolumn{4}{c}{ Tablo 4:Öğretmenlerin kavram kazanım durumları } \\
\hline & $\mathbf{K Y}(\boldsymbol{\%})$ & $\mathbf{K A}_{\mathbf{1}}(\boldsymbol{\%})$ & $\mathbf{K A}_{2}(\boldsymbol{\%})$ & $\mathbf{K K}(\boldsymbol{\%})$ \\
\cline { 2 - 5 } Tüm Madde & 17.7 & 9.02 & 2.59 & 62.3 \\
Oranları & & & & \\
\hline
\end{tabular}

Tablo 4'te sınıf ögretmenlerine yöneltilen test tipi sorulara verilen cevaplardan elde edilen kavram durumları özetlenmiștir. Buna göre öğretmenlerin \%17.7'si kavram yanılgısına sahip ifadeler kullanmışlardır. Öğretmenlerin \%9.02'si kendilerine sorulan sorulara doğru yanıt vermiş ancak tam olarak açılayamamış ve kesinlik güven indeksi oranları düşük olarak nitelendirilmiştir. Öğretmen ifadelerinden \%2.59'su ise yanlış cevap vermiş ancak bu ifadeler kavram yanılgısı olarak nitelendirilmemiştir. Çünkü verilen ifadelerde kesinlik güven indeksi oranının düşük olduğu görülmüştür. Uygulama formuna verilen yanıtlar incelendiğinde öğretmen ifadelerinin \%62.3'ünün ise kavramı tam olarak açıkladıkları ve kavram kazanımlarının gerçekleştiği görülmektedir.

\section{Açık Uçlu Sorularda Tespit Edilen Kavram Yanılgıları}

Öğretmenlere yöneltilen açık uçlu sorulardan alınan yanıtlar listelenmiş ve uzman görüşleri ardından "bilimsel olarak kabul edilebilir, bilimsel olarak kısmen kabul edilebilir ve bilimsel olarak kabul edilemez" kategorilerine ayrılmıștır. Tablo 5'te "Küçük çocuklarda kalp atıș hızının fazla olmasının sebebi nedir?" sorusuna verilen yanıtlar ve bu yanıtların frekansları sunulmuştur. 


\begin{tabular}{|c|c|c|c|}
\hline \multicolumn{4}{|c|}{ Tablo 5:Birinci açık uçlu soruya verilen yanıtlar ve frekansları } \\
\hline \multirow[b]{2}{*}{ İfadeler } & \multicolumn{3}{|c|}{ Bilimsel olarak } \\
\hline & $\begin{array}{l}\text { Kabul } \\
\text { edilebilir } \\
\quad(f)\end{array}$ & $\begin{array}{l}\text { Kismen } \\
\text { kabul } \\
\text { edilebilir } \\
\quad(f)\end{array}$ & $\begin{array}{l}\text { Kabul } \\
\text { edilemez } \\
\quad(f)\end{array}$ \\
\hline Akciğerleri tam gelişmediğinden hava ihtiyacını karşılamak. & & & 3 \\
\hline Vücudun enerji ihtiyacını karşılamaktır. & & & 15 \\
\hline Küçük çocuklarda damarlardaki kan akışı daha hızlıdır. & 4 & & \\
\hline $\begin{array}{l}\text { Çocuklar daha fazla büyüme eğilimi gösterirler. Metabolizmaları } \\
\text { yetişkinlerden daha hızlı çalışır. Bu da kalp atış ve nabız sayısını } \\
\text { etkiler. }\end{array}$ & 24 & & \\
\hline $\begin{array}{l}\text { Vücudundaki oksijen yeterli olmadığı için daha fazla nefes alıp } \\
\text { verir. Bu nedenle daha fazla kalp atışı olur. }\end{array}$ & 4 & & \\
\hline Vücut mekanizmaları sürekli değișkendir. & & & 17 \\
\hline Sık sık nefes alıp vermelerinden kaynaklanır. & & & 9 \\
\hline Küçük çocuklarda kan dolaşımının daha fazla olmasıdır. & & & 6 \\
\hline $\begin{array}{l}\text { Kalp damarlarının diğer organların gelişimine yardımcı } \\
\text { olmasındandır. }\end{array}$ & & & 2 \\
\hline $\begin{array}{l}\text { Bebekler vücutlarında var olan karbonhidratı pompalamak için } \\
\text { yeterli oksijen bulamazlar. O yüzden nabız sayısıyla orantılı olarak } \\
\text { kalp atış hızı fazladır. }\end{array}$ & & & 2 \\
\hline Kalpleri daha küçük olduğu için daha hızlı atar. & & & 7 \\
\hline $\begin{array}{l}\text { Hücrelerin hızla çoğalması ve ölen hücrelerin kendini daha hızlı } \\
\text { yenilemesinden kaynaklanır. }\end{array}$ & & 4 & \\
\hline $\begin{array}{l}\text { Düş dünyayı tanımadıklarından her etkiye tepki verirler ve bu } \\
\text { yüzden kalp atış sayısı çoğalır. }\end{array}$ & & & 1 \\
\hline Nabız sayılarının yüksek olmasından dolayıdır. & & & 4 \\
\hline Küçük çocukların damarlarının daha kısa olmasındandır. & & & 4 \\
\hline Kan basıncının fazla olmasıdır. & & & 2 \\
\hline Bilmiyorum & & & 17 \\
\hline Toplam & 32 & 4 & 89 \\
\hline
\end{tabular}

Tablo 5'te sınıf öğretmenlerinin birinci soru için kullandıkları ifadelerin kategorilere göre frekansları yer almaktadır. Birinci soruya verilen öğretmen yanıtlarına göre, toplam 32 ifadenin bilimsel olarak kabul edilebileceği, 4'ünün bilimsel olarak kısmen edilebileceği ve 89 ifadenin ise bilimsel olarak kabul edilemeyeceği görülmektedir. Öğretmenlerin 17 tanesi bu soruya "bilmiyorum" diyerek cevap vermekten kaçınmışlardır. Bununla birlikte bu soru için bilimsel olarak kabul edilemez kategorisinin en yüksek olduğu $(f=17)$ ifade "Vücut mekanizmalarının sürekli değişken" olmas1 biçimindedir. Bu ifadeyi "Vücudun enerji ihtiyacını karşılamak" $(f=15)$ cevabı takip etmiştir. Soruya verilen tüm yanıtlar arasında en yüksek frekansa "Çocuklar daha fazla büyüme eğilimindedirler. Metabolizmaları yetişsinlerden daha hızlı çalışır. Bu da kalp atış ve nabız sayısını etkiler" ( $f=24)$ ifadesi ile bilimsel olarak kabul edilebilir kategorisinin olduğu görülmektedir. Genel olarak birinci soru için verilen yanıtların bilimsel olarak kabul edilemez olduğu bulgusuna erişilmiştir.

Tablo 6'da "Yaz mevsiminde gündüz süresinin uzun olmasının sebebi nedir?" sorusuna verilen yanıtlar ve bu yanıtların frekansları sunulmuştur. 
Tablo 6: İkinci açı uçlu soruya verilen yanıtlar ve frekansları

\begin{tabular}{|c|c|c|c|}
\hline \multirow[b]{2}{*}{ İfadeler } & \multicolumn{3}{|c|}{ Bilimsel olarak } \\
\hline & $\begin{array}{c}\text { Kabul } \\
\text { edilebilir } \\
(f)\end{array}$ & $\begin{array}{c}\text { Kismen } \\
\text { kabul } \\
\text { edilebilir } \\
(f)\end{array}$ & $\begin{array}{c}\text { Kabul } \\
\text { edilemez } \\
(f)\end{array}$ \\
\hline Dünya’nın Güneş’e olan açısından kaynaklanmaktadır. & & 9 & \\
\hline Güneş ışınlarının dik açıyla gelmesinden kaynaklanmaktadır. & & & 24 \\
\hline Güneş ışınlarının yazın daha uzun süre gelmesidir. & & & 14 \\
\hline Yazın Güneş ışınları kuzey yarımküreye daha yakından düşer. & & & 2 \\
\hline Eksenin daha eğik olmasından dolayı daha fazla Güneş alırız. & & 34 & \\
\hline Dünya’nın yaz mevsiminde Güneş’ten daha uzak olmasıdır. & & 1 & \\
\hline $\begin{array}{l}\text { Dünya'nın yaz mevsiminde Güneş'e daha yakın olmasından } \\
\text { kaynaklanır. }\end{array}$ & & & 4 \\
\hline $\begin{array}{l}\text { Güneş 1şınlarının ekvatordan değil kuzey kutbundan dik olarak } \\
\text { gelmesidir. }\end{array}$ & & & 2 \\
\hline Dünya’nın Güneş etrafinda dönmesi ve $23^{\circ} 27^{\prime}$ eğiminin olması. & & 8 & \\
\hline Çünkü Güneş yazın erken doğar, geç batar. & & & 3 \\
\hline Bilmiyorum & & & 20 \\
\hline Toplam & - & 52 & 69 \\
\hline
\end{tabular}

Tablo 6'da yer alan verilere göre sınıf öğretmenlerinin ikinci soru için vermiş oldukları yanıtların hiçbiri bilimsel olarak kabul edilebilir kategorisinde değildir. 20 öğretmen bu soru için "bilmiyorum" diyerek cevap vermekten kaçınmıştır. Bununla birlikte öğretmen ifadelerinden 52 tanesi bilimsel olarak kısmen kabul edilebilir kategorisinde iken 69 ifade bilimsel olarak kabul edilemez kategorisinde yer almaktadir.

Tablo 7'de "Görselde yer alan aynı cins toplar eşit yükseklikten aynı anda bırakılırsa, hangisi yere daha hızlı düşer? Nedenini açıklayınız” sorusuna verilen yanıtlar ve bu yanıtların frekansları sunulmuştur. 
Tablo 7:Üçüncü açık uçlu soruya verilen yanıtlar ve frekansları

\begin{tabular}{|c|c|c|c|}
\hline \multirow[b]{2}{*}{ İfadeler } & \multicolumn{3}{|c|}{ Bilimsel olarak } \\
\hline & $\begin{array}{l}\text { Kabul } \\
\text { edilebilir } \\
\quad(f)\end{array}$ & $\begin{array}{c}\text { Kismen } \\
\text { kabul } \\
\text { edilebilir } \\
(f)\end{array}$ & $\begin{array}{c}\text { Kabul } \\
\text { edilemez } \\
(f)\end{array}$ \\
\hline $\begin{array}{l}\text { Kütlesi ağır olanın yer çekimi kuvveti daha fazladır. Bu yüzden } \\
\text { ağır olan daha hızlı düşer. }\end{array}$ & & & 26 \\
\hline $\begin{array}{l}\text { Kilosu hafif olan daha hızlı düşser. Çünkü hava sürtünmesi etkili } \\
\text { olur. Hava sürtünmesi ağır cisimlerde daha etkili olur. }\end{array}$ & & & 5 \\
\hline $\begin{array}{l}1 \mathrm{~kg} \text { 'lık top daha önce düşer. Çünkü havanın bir direnci vardır. } \\
\text { Kücük olanda bu direnç az olacaktır. }\end{array}$ & & & 1 \\
\hline $\begin{array}{l}\text { Ağırlığın etkisiyle hız artacağından kütlesi fazla olan daha hızlı } \\
\text { düşer. }\end{array}$ & & & 35 \\
\hline $\begin{array}{l}\text { Uygulanan yer çekimi kuvveti değişmediğinden hepsi aynı anda } \\
\text { düşer. }\end{array}$ & & 25 & \\
\hline Kütlesi az olan daha hızlı düşer. & & & 1 \\
\hline Aynı anda düşer. Madde yoğunluğu esastır. & 2 & & \\
\hline Aynı anda düşer. Serbest düşme kütleye bağlı değildir. & 2 & & \\
\hline $\begin{array}{l}\text { Düşme hızları aynı olur fakat } 20 \mathrm{~kg} \text { 'lik top yere daha önce ulaşır ki } \\
\text { bunun nedeni yer çekimi kuvvetidir. }\end{array}$ & & 1 & \\
\hline $\begin{array}{l}\text { Hepsi aynı anda yere düşer çünkü ağırlık ile hacim arasındaki ilişki, } \\
\text { yere düşme süresini değiştirmez. }\end{array}$ & 1 & & \\
\hline $\begin{array}{l}\text { Kütlesi } 20 \mathrm{~kg} \text { olan top daha hızlı düşser çünkü kütle arttıkça yerin } \\
\text { uyguladığı çekim kuvveti de artacağ için topun kinetik enerjisini } \\
\text { artırır. Bu da hızın artmasında neden olur. }\end{array}$ & & 1 & \\
\hline $\begin{array}{l}\text { Kütlesi fazla olan yere daha fazla basınç uygular. Bu nedenle daha } \\
\text { hızlı düşer. }\end{array}$ & & & 3 \\
\hline $\begin{array}{l}\text { Küçük olan daha çabuk düşer. Büyük yüzeylerde sürtünme daha } \\
\text { fazla olur. O da büyük yüzeyin düşmesini yavaşlatır. }\end{array}$ & 1 & & \\
\hline $\begin{array}{l}\text { Potansiyel enerji kinetik enerjiye eşit olacaktır. Dolayısıyla kütleye } \\
\text { bağlı olmadığından eşit yükseklikten bırakıldığında yere aynı hızla } \\
\text { düşerler. }\end{array}$ & 1 & & \\
\hline $\begin{array}{l}\text { Havası alınmış bir ortamda yapılıyorsa hepsi aynı anda düşer. } \\
\text { Normal şartlarda } 20 \mathrm{~kg} \text { olan yer çekiminden dolayı daha hızlı } \\
\text { düşer. }\end{array}$ & & 3 & \\
\hline Küçük olan daha hızlı düşer. Önemli olan kütle değil sürtünmedir. & 5 & & \\
\hline Bilmiyorum & & & 8 \\
\hline Toplam & 12 & 30 & 79 \\
\hline
\end{tabular}

Tablo 7'de ise öğretmenlere yöneltilen son açık uçlu soru için verilen yanıtlar yer almaktadır. Buna göre son soru için öğretmen ifadelerinden 12 tanesi bilimsel olarak kabul edilebilir, 30 tanesi bilimsel olarak kısmen edilebilir ve 79 tanesi bilimsel olarak kabul edilemez kategorisinde yer almaktadır. Ayrıca 8 öğretmen bu soruya "bilmiyorum" ifadesiyle cevap vermemiştir. Son soru için genel olarak öğretmenlerin bilimsel olarak kabul edilemeyen kategoride yanıt verdikleri görülmüştür.

\section{Tartışma, Sonuç ve Öneriler}

$\mathrm{Bu}$ çalışmada sınıf öğretmenlerinin fene ilişkin kavram yanılgıları test tipi ve açık uçlu sorularla belirlenmeye çalışılmıştır. Test tipinde öğretmenlere toplam 6 soru yöneltilmiş ve öğretmenlerden her soru için birden fazla yanıt alınmıştır. Alınan yanıtlara göre sınıf öğretmeni ifadeleri büyük oranda (\%62.3) kavram kazanımının gerçekleştiğini bununla birlikte öğretmenlerin kavram yanılgılarına da sahip olduklarını göstermektedir (\%17.7). Tohumların canlılı̆̆ soruya verilen yanıtlara göre 2 ifade kavram yanılgısı içermekte iken, 101 ifade kavram kazanımının 
gerçekleştiğini göstermektedir. Tohumların canlılığı konusunda büyük oranda kavram kazanımının gerçekleşmiş olması, sınıf öğretmenlerinin bu konuyla ilişkili deneyim ve gözlemlerinin fazla olması ile açıklanabilir. Bununla birlikte balinaların sınıflandırılması konusuyla ilgili olarak yöneltilen soruda 40 kavram yanılgısı ifadesi yer almıştır. Trowbridge ve Mintzes (1988) ile Yen, Yao ve Chiu (2004) bireylerin canlıların sınıflandırılması konusunda sahip oldukları kavram yanılgılarını çoğunlukla canlı özellikleri yerine yaşam alanlarının dikkate alınması durumu ile ilişkilendirmektedirler. Buna göre gerek öğrenciler gerekse öğretmenler, canlıları sınıflandırırken canlıya ilişkin var olan dışsal bazı morfolojik özelliklere, vücutlarını kaplayan yapıya ya da vücudun bölümleri gibi algılara göre hareket etmektedirler. $\mathrm{Bu}$ algilar bireylerde canlıların sinıflandırılması konusunda yeni bir zihinsel model geliştirilmesine yol açmakta (Halford,1993) ve kavramsal anlamalarda zorluklara sebebiyet vermektedir (Yen vd., 2004).

Sınıf öğretmenlerine, karanlık odada beyaz bir kağıdın görülebilmesi ile uçaktan atlayan biri üzerindeki yerçekimi kuvvetinin sorulduğu sorulara verilen yanıtlar, bu sorular için kavram kazanımı düzeyinin yüksek olduğunu ancak beraberinde kavram yanılgılarının da olduğunu göstermektedir. İlgili literatürde ilkokul öğrencilerinde tespiti yapılan (Şahin vd., 2008) karanlık bir odada beyaz kağıdın görülebileceği düşüncesi, öğretmenler tarafından beyaz rengin yansitıcı olduğu düşüncesiyle destek bulmuştur. Şen'in (2003) ilköğretim öğrencileriyle yürütmüş olduğu çalışma sonuçları da görme olayında maddelerin görülebilmesinin yansıtma olayı ile açıklandığını göstermektedir. Kimi öğretmen ifadelerinde yer alan gözün bir süre karanlık ortama alışması sonucu beyaz kağıdın görülebileceği düşüncesi, görme olayında 1şık kaynağ1 olarak gözün kabul edilebileceği ihtimalini düşündürmektedir. Hardman ve Riordan (2014) ilkokul ve ortaokul düzeyindeki öğrencilerle 1şı̆̆ın anlaşılması konusunda yürütmüş oldukları PIPER (Institute of Physics Promoting and Interpreting Physics Education Research) projesinin bir parçası olarak öğrencilerin görme olayını açıklarken gözden cisimlere doğru 1şığın iletildiği ve görmenin bu şekilde sağlandığı düşüncesinde olduklarını ortaya çıkarmışlardır. Dolayısıyla öğretmenler tarafından görme olayı tam olarak bu şekilde ifade edilmemiş olmasına rağmen benzer bir anlaşılmanın olması muhtemel gözükmektedir. Bu durum aynı zamanda görme olayında ışığın rolü ve öneminin tam olarak anlaşılmadığına da işaret etmektedir. Uçaktan atlayan bir kişi üzerinde herhangi bir yer çekimi kuvvetinin var olup olamayacağının sorgulandığı soruda öğretmenlerin "yer çekimi kuvveti olmasaydı zaten aşağıya düşemezdi" biçiminde açıklamaları oldukça sık biçimde ifade edilmiştir. Bununla birlikte yerçekimi kuvvetini sadece Dünya'nın merkezinde olduğunu kabul eden öğretmen görüşleri yer almıştır. Pablico (2010) yüksekokul öğrencileri ile yürütmüş olduğu tez çalışmasında, öğrencilerin büyük bir çoğunluğunun yanılgıya düştüklerini ve gökyüzünde yer çekiminin olamayacağını bildirdiklerini belirtmiştir. Gustone ve arkadaşlarına (1989, aktaran Pablico, 2010) göre uçaktan aşağ 1 serbest düşme esnasında rakımla birlikte yerçekimi kuvveti de azalmaktadır. Yaklaşık 32.000 metrelik bir irtifa kaybı ve dolayısıyla \%1'lik yerçekimi kuvveti azalması muhtemel olarak kabul edilmektedir.

Sınıf öğretmenlerine ait en fazla kavram yanılgısının, paslanmış demir sorusuna verilen yanıtlarda olduğu görülmüştür. Bu soruya verilen yanıtlar genel bir çerçevede özetlenecek olursa; paslanan demirin ağırlığında bir değişme olmayacağı, paslanan demirin ağırlaşacağı çünkü üzerinde kir ve bakterinin birikeceği, paslanmış demirin hafifleyeceği çünkü paslanma ile birlikte dökülmelerin olup kütlesinden kaybedeceği biçiminde ya da sorunun cevapsız bırakılarak geçildiği görülmüştür. Burada verilen en ilginç yanıtların, paslanan demirin üzerinde bakteri ve kirlerden dolayı bir ağırlaşmanın olduğu düşüncesine ait olduğu görülmektedir. Çünkü sınıf öğretmenlerine göre paslanma olayı kirlenme olarak algılanmaktadır. Elde edilen bu bulgu Allen'in (2014) ilkokul öğrencilerinde tespit ettiği bir yanılgıdır. Bununla birlikte kimi öğretmenlerde paslanma ile çürümenin birlikte algılandığı ve öz kütlede bir azalmaya yol açacağı düşüncesinin hakim olduğu görülmüştür. Dolayısıyla sınıf öğretmenlerinin paslanma konusunda ciddi yanılgıları olduğunu söylemek mümkündür. 
Öğretmenlere sorulan son test tipi soruda ise pedal çevrilmediği halde bisiklet üzerindeki yavaşlatıcı etkinin ne olduğu sorgulanmıştır. Ancak bu soruda öğretmen yanıtlarının çeşitlilik gösterdiği tespit edilmiştir. Soruya 15 öğretmen "bilmiyorum" yanıtı verirken, öğretmen ifadelerinden 50 'sinin kavram kazanımının olduğu, 15 ifadenin kavramdan tam olarak emin olamadığı, 10 ifadenin ise kavram yanılgısı içerdiği görülmüştür. Pablico'nun (2010) çalışmasında elde edilen sonuca göre fizik grubunda yer alan öğrencilerin \%26'sı bisikleti yer çekimi kuvvetinin yavaşlattığını düşünürken \%20'lik bir grubun kuvvetin etkisinin devam ettiği şeklinde yanıt verdikleri görülmüştür. Ayrıca geriye kısım bisiklet üzerindeki kişinin ağırlığından dolayı bir yavaşlama olacağını bildirmiştir. Dolayısıyla bu çalışma ile Pablico'nun (2010) çalışmasında elde edilen bulguların paralellik gösterdiği tespit edilmiştir. Bu durum sınıf öğretmenlerinin ilkokul, ortaokul ve yüksekokul öğrencileri ile benzer yanılgılara sahip olduğunu göstermektedir. Bununla birlikte öğretmenlerin yerçekimi kuvveti konusunda bilgilerinin var olduğunu ancak hava direnci ya da sürtünme konularına hakimiyetin olmadığını da söylemek mümkündür.

Çalışmanın ikinci kısmında sınıf öğretmenlerine 3 adet açık uçlu soru yöneltilmiş ve onlardan gelen yanıtlar uzman görüşleri doğrultusunda kategorilere ayrılmıştır. Sorulan ilk açık uçlu soru araştırmacılar tarafından geliştirilmiş olup ilgili literatürde daha önce tespitinin yapılmadı̆̆ görülmüştür. Küçük çocuklardaki kalp atış hızı ile ilgili olan soruda 32 öğretmen ifadesi bilimsel olarak kabul edilirken, "bilmiyorum" ifadesi dışında 72 öğretmen ifadesi bilimsel olarak kabul edilmeyen kategorisinde toplanmıştır. Ancak çalışmada yer alan bu soru sınıf öğretmenlerinin öğretimleri esnasında kullandıkları ve dördüncü sınıf ders kitaplarında cevabını barındıran (URL-1) bir özelliğe sahiptir. Nitekim öğretmenlerin bu konuda yeterli olmadıkları tespit edilmiştir. Ulaşılan bu bulgunun ilgili literatüre katkı sağlayacağı düşünülmektedir.

Öğretmenlere sorulan ikinci açık uçlu soruda yaz mevsiminde gündüz süresinin uzun olmasının nedeni sorgulanmış ancak sınıf öğretmenlerinden bilimsel olarak kabul edilebilir bir cevap alınamamıştır. 52 öğretmen ifadesinin bilimsel olarak kısmen kabul edilebilir kategorisinde olduğu tespiti yapılırken, 20 öğretmen cevap vermemiş, 49 öğretmen ifadesi ise bilimsel olarak kabul edilemeyen kategorisine yerleştirilmiştir. Günlük yaşamla alakalı bu bilgiye ilişkin elde edilen bulgular ilgili literatürde de desteklenmektedir. Öğretmenlerin yaz mevsimini Dünya'nın Güneş’e yaklaşması ile ilişkilendirmesi; Ünsal, Güneş ve Ergin (2001) ile Trumper'in (2000) üniversite öğrencileriyle yürütmüş oldukları çalışmada elde ettikleri bulgulara benzerdir. Öğretmenlerin yaz mevsimini Dünya'nın Güneş'ten uzaklaşması ile ilişkilendirmesi durumu ise Küçüközer (2007), Ünsal ve arkadaşları (2001) ile Trumper'in (2000) yine üniversite öğrencileriyle yürütmüş oldukları çalışmada elde edilen benzer bulgulardır. Ulaşılan bu bulgular dışında sınıf öğretmenlerinin, yazın Güneş 1şınlarının Dünya'ya daha uzun süre gelmesi, Güneş 1şınlarının ekvator ya da kuzey kutbundan gelmesi ile ilişkilendirilmesi ile Güneş'in erken doğup geç batması gibi literatürde olmayan cevaplar sundukları da görülmüştür. Tüm bu cevaplar alınan uzman görüşlerine dayanarak birer kavram yanılgısı olarak değerlendirilmiştir.

Öğretmenlere sunulan son açık uçlu soruda ise eşit yükseklikten aynı anda bırakılan aynı cins topların yere düşme hızları sorulmuştur. 8 öğretmen bu soruya yanıt vermezken, 12 öğretmen ifadesi bilimsel olarak kabul edilebilir, 30 ifade bilimsel olarak kısmen kabul edilebilir ve 71 ifade bilimsel olarak kabul edilemez kategorisine yerleştirilmiştir. Howe, Taylor Tavares ve Devine (2012) 6-10 yaş grubundaki öğrencilerle bir bilgisayar programı üzerinden sıcak hava balonu ile yukarı havalanan bir balondan aşağı doğru atılan cisimlerin havadaki ve sudaki hareketleri, yönleri ve düşme hızları konusunda tahmin ve tanımlamaya ilişkin bir çalışma yürütmüşlerdir. Yürütülen bu çalışma öğrencilerin cinsiyetleri, bilgisayar kullanımları ve el becerileri değişkenleri üzerinden incelenmiştir. İnceleme sonucuna göre küçük çocuklarda topun hareketi ve düşme hızı konusunda yanılgıya düştükleri görülmüştür. Buna göre daha ağır cisimlerin daha hızlı daha hafif cisimlerin ise yavaş düştükleri kabul edilmektedir. Benzer yanılgılara ortaokul ve lise öğrencilerinde de rastlanmıştır (Osborne, 1984). Bu çalışmada elde edilen bulgular, ilgili literatürde rastlanan bu yanılgıların 
öğretmenlerde de olduğunu göstermektedir. Bu durum Howe ve arkadaşları (2012) tarafından günlük yaşam becerileri ile kavramsal bilgiler arasında ilişki kurulamamasından kaynaklı olarak kabul edilmektedir.

Sınıf öğretmenleriyle yürütülen bu çalışma esasında, sınıf öğretmenlerinin kavram yanılgılarına ilişkin ne bildikleri, öğretimlerinde buna nasıl yer verdikleri ve öğretimlerinde karşılaşacakları yanılgılar noktasında nasıl bir düzenlemeye gidecekleri noktasında da 1şık tutmaktadır. Çünkü elde edilen oldukça çarpıcı bu bulgular, sınıf öğretmenlerinin ilgili literatürde daha önce ilkokul, ortaokul, lise ve üniversite öğrencilerinde var olan kavram yanılgıları ile benzer yanılgılara sahip olduklarını göstermektedir. Alkış Küçükaydın'ın (2019) sınıf öğretmenlerinin fen kavram yanılgılarına ilişkin zihinsel modellerini incelendiği çalışmasında, sınıf öğretmenlerinin kavram yanılg1sı konusunda teorik düzeyde de yeterli düzeyde bilgiye sahip olmadıkları görülmüsstür. $\mathrm{Bu}$ durum üzerinde durulması, düzeltilmesi ve aydınlatılması gereken bir husustur. Ancak hizmet içindeki öğretmenlerle gerek uygulama gerekse veri toplama noktasında karşılaşılan zorluklar dikkate alındığında sağlam bir planlamaya ihtiyaç duyulduğu görülmektedir. Dolayısıyla bu planlamanın yerelde değil ulusal düzeyde ihtiyaçlara verecek nitelikte hazırlanması ve sınıf öğretmenlerinin kavram yanılgılarının sadece tespit değil, kökenlerinin araştırılması ve giderilmesi konusunda nitelikli projelere ihtiyaç duyulmaktadır. Bir fen bilgisi öğretmeninin ihtiyaç duyacağı kavram bilgisi ile sınıf öğretmeninin sahip olduğu ihtiyaç perspektif açısından farklılık gösterecektir. Dolayısıyla bu noktada öncelikle sınıf öğretmenlerinin sahip oldukları kavram bilgileri ile sınıf ortamındaki pratikte yer alan uzmanlık bilgilerinin seviyesinin ölçülerek işe başlanması önerilebilir. Sınıf öğretmenlerinin bilimsel olarak kavram yanılgıları ile yüzleşmeye hazır hale getirilmesi ve kendilerini yenileme noktasında isteklerinin artırılması, geliştirilecek ulusal öğretmen yetiştirme hedefleri arasına sokulabilir.

\section{KAYNAKÇA}

Alkış Küçükaydın, M.(2019). Sınıf öğretmenlerinin fen kavram yanılgılarına ilişkin zihinsel modelleri. Eğitim ve İnsani Bilimler Dergisi: Teori ve Uygulama, 10(9), 132-152.

Akbaş, Y. (2002). Illköğretim 6. sinıf örgencilerinin coğrafi kavramları anlama düzeyleri ve kavram yanılgıları. Yayımlanmamış yüksek lisans tezi. Karadeniz Teknik Üniversitesi, Trabzon.

Akgün, A., Gönen, S., \& Yılmaz, A. (2009). Fen öğretmen adaylarının buhar basıncı ve kaynama noktası arasındaki ilişki ile ilgili bilgi eksiklikleri ve kavram yanılgıları. Education Sciences, 4(1), 13-24.

Alkış, S. (2006). İlköğretim öğrencilerinin yağış kavramını algılamaları üzerine bir araştırma. Yayımlanmamış doktora tezi. Uludağ Üniversitesi, Bursa.

Allen M. (2014). Misconceptions in primary science. England, Open University Press.

Arslan, H. O., Çiğdemoğlu, C., \& Moseley, C. (2012). A three-tier diagnostic test to assess pre-service teachers' misconceptions about global warming, greenhouse effect, ozone layer depletion, and acid rain. International journal of science education, 34(11), 1667-1686.

Avcı, D. E., Kara, İ., \&Karaca, D. (2012). Fen bilgisi öğretmen adaylarının iş konusundaki kavram yanılgıları. Pamukkale Üniversitesi Eğitim Fakültesi Dergisi, 31(31), 27-39.

Ayvacı, H.Ş.,\& Şenel Çoruhlu, T. (2009). Fiziksel ve kimyasal değişim konularındaki kavram yanılgılarının düzeltilmesinde açıklayıcı hikâye yönteminin etkisi. Ondokuz Mayıs Üniversitesi Eğitim Fakültesi Dergisi, 28(1), 93-104.

Barrass, R. (1984). Some misconceptions and misunderstandings perpetuated by teachers and textbooks of biology. Journal of Biological Education, 18(3), 201-206. 
Bayraktar, S. (2009). Misconceptions of Turkish pre-service teachers about force and motion. International Journal of Science and Mathematics Education, 7(2), 273-291.

Cheung, D., Ma, H. J., \& Yang, J. (2009). Teachers' misconceptions about the effects of addition of more reactants or products on chemical equilibrium. International Journal of Science and Mathematics Education, 7(6), 1111-1133.

Çakır, M.,\& Aldemir, B. (2011).İki aşamalı genetik kavramlar tanı testi geliştirme ve geçerlik çalışması. Mustafa Kemal Üniversitesi Sosyal Bilimler Enstitüsü Dergisi, 8(16), 335-353.

Çavdar, O.,Okumuş, S., \& Doymuş, K. (2016). Fen eğitimi öğrencilerinin maddenin tanecikli yapısıyla ilgili anlamalarının belirlenmesi. Mustafa Kemal Üniversitesi Sosyal Bilimler Enstitüsü Dergisi, 13(3), 69-93.

Çıbık, A. (2017). Determining science teacher candidates' academic knowledge and misconceptions about electric current. Educational Sciences: Theory and Practice, 17(3), 1061-1090.

Dankenbring, C., \&Capobianco, B. M. (2016). Examining elementary school students' mental models of sun-earth relationships as a result of engaging in engineering design. International Journal of Science and Mathematics Education, 14(5), 825-845.

EyceyurtTürk, G., \&Tüzün, Ü. N. (2018). Pre-Service science teachers' images and misconceptions of atomic orbital and self-ionization concepts. Universal Journal of Educational Research, 6(3), 386-391.

Gomez-Zwiep, S. (2008). Elementary teachers' understanding of students' science misconceptions: Implications for practice and teacher education. Journal of Science Teacher Education, 19(5), 437-454.

Güler, B.,\& Şahin, M. (2017). Fen bilgisi öğretmen adaylarının "elektrik ve manyetizma” konusundaki kavramsal anlamalarının incelenmesi. Buca Eğitim Fakültesi Dergisi, 44, 179-193.

Halford, G.S. (1993). Children's understanding: The development of mental models. Hillsdale, NJ: Lawrence Erlbaum Associates.

Hardman, M., \& Riordan, J. P. (2014). How might educational research into children's ideas about light be of use to teachers? Physics Education, 49(6), 644-664.

Hasan, S., D. Bagayoko, D., \& Kelley, E. L. (1999). Misconceptions and the certainty of response index (CRI). Journal Physics Education, 34(5), 294-299.

Hashweh, M. Z. (1987). Effects of subject-matter knowledge in the teaching of biology and physics. Teaching and teacher education, 3(2), 109-120.

Howe, C., Taylor Tavares, J., \& Devine, A.(2012).Everyday conceptions of object fall: Explicit and tacit understanding during middle childhood. Journal of Experimental Child Psychology,111, 351-366.

Kaptan, F., \& Korkmaz, H. (2001). Hizmet öncesi sınıf öğretmenlerinin fen eğitiminde 1s1 ve sıcaklıkla ilgili kavram yanılgıları. Hacettepe Üniversitesi Eğitim Fakültesi Dergisi, 21, 59-65.

Karasar, N. (2013). Bilimsel araştırma yöntemi. Ankara, Nobel Yayınevi.

Kırıkkaya, E. B., \& Güllü, D. (2008). İlköğretim beşinci sınıf öğrencilerinin 1S1-sıcaklık ve buharlaşma-kaynama konularındaki kavram yanılgıları. İlköğretim Online, 7(1),15-27.

Kikas, E. (2004). Teachers' conceptions and misconceptions concerning three natural phenomena. Journal of Research in Science Teaching: The Official Journal of the National Association for Research in Science Teaching, 41(5), 432-448. 
Koray, Ö., Özdemir, M., \& Tatar, N. (2005). İlköğretim öğrencilerinin" birimler" hakkında sahip oldukları kavram yanılgıları: Kütle ve ağırlık örneği. İlköğretim Online, 4(2),24-31.

Küçüközer, H.(2007).Prospective science teachers' conceptions about astronomical subjects. Science Education International, 18(2), 113-130.

Kruger, C., Palacio, D. \& Summers, M. (1992). Surveys of English primary school teachers' conceptions of force, energy and materials. Science Education, 76(4), 339-351.

Lawrenz, F. (1986). Misconceptions of physical science concepts among elementary school teachers. School Science and Mathematics, 86, 654-660.

Meyer, H. (2004). Novice and expert teachers' conceptions of learners' prior knowledge. Science Education, 88(6), 970-983.

Milli Eğitim Bakanlığı (MEB) (2018). İlköğretim kurumları (ilkokullar ve ortaokullar) fen bilimleri dersi $(3,4,5,6,7$ ve 8. sinıflar) ögrretim programı. Talim ve Terbiye Kurulu Başkanlığı, Ankara.

Naah, B. M. (2015). Enhancing preservice teachers' understanding of students' misconceptions in learning chemistry. Journal of College Science Teaching, 45(2), 41-47.

Osborne, R.(1984). Children's' dynamics. The Physics Teacher, 22, 504-508.

Pablico, J.R. (2010). Misconceptions on force and gravity among high school students. LSU Master's Theses. Louisiana State University and Agricultural and Mechanical College.

Pine, K., Messer, D., \& St. John, K. (2001). Children's misconceptions in primary science: A survey of teachers' views. Research in Science \& Technological Education, 19(1), 79-96.

Platten, L. (1995). Talking geography: An investigation into young children'sunderstanding of geographical terms part-1. International Journal of Early YearsEducation, 3(1), 74-91.

Sanders, M. (1993). Erroneous ideas about respiration: The teacher factor. Journal of research in science teaching, 30(8), 919-934.

Selvi, M., \&Yakışan,M. (2004). Üniversite birinci sınıf öğrencilerinin enzimler konusu ile ilgili kavram yanılgıları. Gazi Üniversitesi Gazi Eğitim Fakültesi Dergisi, 24(2), 173-182.

Subayani, N.W. (2016). The profile of misconceptions among science subject student-teachers in primary schools. International Journal of Education \& Literacy Studies, 4(2), 54-61.

Şahin, Ç.,İpek,H., \&Ayas, A. (2008). Students' understanding of light concepts primary school: A cross-age study. Asia-Pacific Forum on Science Learning and Teaching,9(1), 1-19.

Şen, A.İ. (2003). İlköğretim öğrencilerinin 1şık, görme ve aynalar konusundaki kavram yanılgılarının ve öğrenme zorluklarının incelenmesi. Hacettepe Üniversitesi Eğitim Fakültesi Dergisi, 25, 176-185.

Tamir, P., Gal-Chappin, R., \&Nussnovitz, R. (1981). How do intermediate and junior high school students conceptualize living and non-living? Journal of Research in Science Teaching, 18, 241-248.

Trowbridge, J., \&Mintzes, J. (1988). Alternative conceptions in animal classification: A cross age study. Journal of Research in Science Teaching, 25, 547-571.

Trumper, R.(2000). University students' conceptions of basic astronomy concepts. Physics Education, $35(1), 9-15$. 
Trumper, R., Raviolo, A. \&Shnersch, A. (2000). A cross cultural survey of conceptions of energy among elementary school teachers in training: Empirical results from Israel and Argentina. Teaching and Teacher Education, 16, 697-714.

URL-1. http://www.eba.gov.tr/ekitap?\&channel=134\&sort=newestadresinden 25.12.2018 tarihinde erişilmiştir.

Ünsal, Y., Güneş, B.., \& Ergin, İ. (2001). Yükseköğretim öğrencilerinin temel astronomi konularındaki bilgi düzeylerinin tespitine yönelik bir araştırma. Gazi Üniversitesi Gazi Eğitim Fakültesi Dergisi, 21(3),47-60.

White, R. \&Gunstone, R. (1992). Probing understanding. London, TheFalmer Press.

Yates, T. B., \&Marek, E. A. (2014). Teachers teaching misconceptions: a study of factors contributing to high school biology students' acquisition of biological evolution-related misconceptions. Evolution: Education and Outreach, 7(1), 1-18.

Yen, C. F., Yao, T. W., \& Chiu, Y. C. (2004). Alternative conceptions in animal classification focusing on amphibians and reptiles: A cross-age study. International Journal of Science and Mathematics Education, 2(2), 159-174.

Yip, D. Y. (1998). Teachers' misconceptions of the circulatory system. Journal of Biological Education, 32(3), 207-215. 